\title{
Imunisasi AGE-BSA Mempengaruhi Kadar Glukosa Darah, AGE dan Antibodi Anti AGE Serum pada Mencit Diabetik Nefropati
}

\author{
Nurona Azizah ${ }^{1}$, Musthika Wida Mashitah ${ }^{2}$, Nur Samsu $^{3}$ \\ ${ }^{1}$ Jurusan Keperawatan, Fakultas Kedokteran, Universitas Brawijaya, Malang, Indonesia \\ ${ }^{2}$ Jurusan Keperawatan, Politeknik Kesehatan dr. Soepraoen, Malang, Indonesia \\ ${ }^{3}$ Departemen Nefrologi-Hipertensi, Rumah Sakit Umum Dr. Syaiful Anwar Malang \\ Penulis untuk Korespondensi/E-mail: nurona.azizah@ub.ac.id
}

\begin{abstract}
Abstrak - Diabetik nefropati adalah salah satu komplikasi serius dari diabetes melitus dan menjadi penyebab penting dari gagal ginjal stadium akhir. Salah satu kondisi hiperglikemia menyebabkan nefropati adalah melalui jalur pembentukan Advanced Glycation End Products (AGE). Saat ini, terapi hanya berkisar obat-obatan anti-AGE yang harus dikonsumsi terusmenerus sehingga kurang efisien. Untuk itu, imunisasi dapat menjadi kandidat terapi yang lebih baik. Penelitian ini mengamati efek imunisasi antigen AGE-BSA dalam menurunkan kadar gula darah, serum AGE, dan serum antibodi anti AGE. Penelitian ini menggunakan desain true experimental laboratory dan metode Randomized Posttest Only Control Group Design. Mencit dibagi menjadi empat kelompok; Grup I mendapatkan PBS, Grup II diinjeksi STZ, Grup III diberikan imunisasi AGE-BSA, dan Grup IV diimunisasi AGE-BSA kemudian diinjeksi STZ. Penegakan diabetik nefropati apabila glukosa darah pada Grup II $\geq 280 \mathrm{mg} / \mathrm{dL}$. Dua belas minggu post injeksi STZ terakhir, kadar AGE dan antibodi anti AGE serum diukur menggunakan kit ELISA. Hasil menunjukkan jika imunisasi AGE-BSA secara signifikan menurunkan kadar glukosa darah dan AGE serum $(p=0.000 ; p<0.05)$, namun meningkatkan secara signifikan kadar antibodi anti AGE serum ( $<$ 0.05). Sebagai tambahan, imunisasi AGE-BSA pada Grup III tidak menunjukkan perbedaan signifikan dengan mencit normal (Grup I), mengindikasikan imunisasi ini tergolong aman bagi variabel yang diukur. Kesimpulan dari penelitian ini adalah imunisasi AGE-BSA mampu menurunkan kadar glukosa darah dengan menghambat pembentukan AGE.
\end{abstract}

\section{Kata Kunci - AGE-BSA, glukosa darah, diabetik nefropati}

Abstract - Diabetic nephropathy is one of serious complication from diabetes mellitus and become vital cause of end-stage renal disease. One path how hyperglycemic condition causes nephropathy is through the formation of Advanced Glycation End Products (AGE). Recently, therapies related AGE still use medicine only which need to be consumed routinely thus less effective. Thus, immunization may be a better candidate therapy. We observed the immunization effect using AGE-BSA antigen in decreasing blood glucose, serum AGE, and antiAGE antibody levels. This study used true experimental laboratory with randomized post-test only control group design. Mice were randomly divided into four groups; Group I received PBS, Group II was given STZ, Group III was immunized AGE-BSA, Group IV was immunized AGE-BSA followed with STZ injection. Diabetic nephropathy confirmed when blood glucose reached $\geq 280 \mathrm{mg} / \mathrm{dL}$. Twelve weeks post last STZ injection, the level of AGE and anti-AGE antibody from serum were measured using ELISA Kit. Result showed that immunization of AGE-BSA significantly decreased blood glucose and AGE level $(p=0.000 ; p<0.05)$ whereas, the level of anti-AGE antibody was significantly increased in Group IV (p < 0.05). Additionally, immunization in Group III showed no any difference with Group I, indicating this immunization might be safe therapy for the variables measured. The conclusion of this 
research that AGE-BSA immunization is able to decrease the level of blood glucose in diabetic nephropathy through inhibition of AGE formation.

Keywords - AGE-BSA, blood glucose, diabetic nephropathy

\section{PENDAHULUAN}

$\mathrm{D}_{\mathrm{n}}^{\mathrm{i}}$ Indonesia, diabetik nefropati (DN) merupakan penyebab kedua $(17,54 \%)$ pasien menjalani hemodialisis pada tahun 2000 . Indonesia juga merupakan negara dengan frekuensi penyakit ginjal diabetik asimtomatik tertinggi di antara negara yang mengikuti studi Developing Education on Microalbuminuria for Awareness of Renal and Cardiovascular Risk in Diabetes (DEMAND) di dunia pada tahun 2009 [1,2]. Salah satu jalur hiperglikemia menyebabkan nefropati adalah melalui pembentukan AGE (advanced glycation end product). AGE merupakan produk protein terglikasi yang terbentuk akibat kondisi hiperglikemi jangka panjang [3].

AGE di jaringan (intraselular) maupun AGE di sirkulasi (ekstraselular) berkontribusi dalam progresivitas DN. Cross-link antara AGE dengan ECM (extra celullar matrix) memperburuk terjadinya glomerulosklerosis. Interaksi antara AGE dalam sirkulasi dengan RAGE (receptor for advanced glycation end product) pada sel mesangeal, tubular, dan podosit akan meningkatkan produksi ROS intraseluler dan upregulasi dari faktor transkripsi NF- $\kappa \mathrm{B}$ yang selanjutnya meningkatkan transkripsi VEGF, MCP-1, ICAM-1, VCAM-1，CTGF，RAGE， sitokin inflamasi IL-1, IL-6, TNF- $\alpha$, dan terutama TGF- $\beta$ sebagai mediator sentral fibrosis. Kesemuanya merupakan faktor pemicu nefropati yang dimanifestasikan dengan hiperpermeabilitas dan hiperfiltrasi glomerulus, proteinuria, inflamasi, akumulasi ECM, penebalan GBM (glomerular basal membrane), ekspansi mesangeal, hipertrofi glomerulus, glomerulosklerosis, dan tubulointerstitial fibrosis [4-6].

Pengembangan imunisasi akan menjadi terapi menjanjikan di masa depan karena pengobatan anti-AGE yang masih bersifat "konsumsi terusmenerus" [7]. Pada dasarnya AGE yang terdiri dari berbagai macam protein terglikasi memiliki sifat antigenik yang memicu terbentuknya autoantibodi dalam tubuh, namun masih belum jelas perannya apakah bersifat protektif atau justru memperparah DN [8].

\section{Tujuan Penelitian}

Penelitian ini bertujuan untuk mengidentifikasi peran imunisasi AGE-BSA terhadap kadar glukosa darah, AGE serum, dan antibodi anti AGE serum pada mencit yang diinduksi diabetik nefropati.

\section{Manfaat Penelitian}

Manfaat dari penelitian ini adalah memberikan informasi dasar pengaruh imunisasi AGE-BSA terhadap kadar glukosa darah, kadar AGE serum, dan antibodi anti-AGE serum pada mencit yang dinduksi diabetik nefropati. Saat ini pengobatan AGE masih berbasis obat yang dikonsumsi secara terus-menerus, sehingga hasil temuan ini diharapkan memberikan wawasan baru jika terapi berbasis vaksinasi mungkin menjadi kandidat terapi pengganti yang lebih baik.

\section{METODE PENELITIAN}

\section{Jenis Penelitian}

Penelitian ini merupakan penelitian experimental dengan desain true experimental laboratory dan metode Randomized Posttest Only Controlled Group Design yang bertujuan mengidentifikasi peran imunisasi AGE-BSA terhadap kadar glukosa darah, AGE serum, dan antibodi anti AGE serum pada mencit yang diinduksi diabetik nefropati.

\section{Tempat dan Waktu Penelitian}

Pembuatan antigen AGE-BSA dan pemeriksaan variabel dilakukan di Laboratorium Biomedik FKUB, pemeliharaan hewan coba di Laboratorium Farmakologi FKUB, Biomedik FKUB. Penelitian ini diselesaikan dalam waktu 1 tahun.

\section{Subyek dan Kriteria Inklusi Penelitian}

Hewan coba yang digunakan dalam penelitian ini adalah mencit galur Balb/C jantan yang diperoleh di Pusat Penelitian Farmako Universitas Brawijaya. Pemakaian mencit 
sebagai hewan coba yang mudah ditangani, mudah dipelihara, dan mudah berkembangbiak. Kriteria mencit yang digunakan pada penelitian ini termasuk galur Balb/C, jenis kelamin jantan, umur 6-8 minggu, berat badan 20-25 gram, dan kondisi sehat yang ditandai dengan gerakan yang aktif.

\section{Hewan Coba}

Mencit diadaptasi 7 hari di Lab. Farmakologi, Fakultas Kedokteran, Universitas Brawijaya dengan pembagian 4 kelompok $(n=20)$. Grup I atau mencit normal hanya diberikan PBS; Grup II atau mencit DN adalah mencit yang hanya diinjeksi STZ dosis rendah $55 \mathrm{mg} / \mathrm{kgBB}$ 1x1 selama 5 hari via intraperitoneal; Grup III adalah mencit yang hanya diimunisasi AGEBSA; dan Grup IV adalah mencit yang diimunisasi AGE-BSA yang dilanjutkan dengan injeksi STZ dosis rendah $55 \mathrm{mg} / \mathrm{kgBB}$ $1 \mathrm{x} 1$ selama 5 hari via intraperitoneal.

\section{Pembuatan AGE-BSA}

Glycated Bovine Serum Albumin (AGE-BSA) diproduksi dengan menginkubasi BSA (50 $\mathrm{mg} / \mathrm{mL}$ ) dan $0.5 \mathrm{M}$ glukosa pada suhu $50^{\circ} \mathrm{C}$ selama 4 hari [10].

\section{Imunisasi AGE-BSA}

Setelah mencit beradaptasi 7 hari di Laboratorium Farmakologi FKUB, mencit diimunisasi secara intraperitoneal dengan injeksi $50 \mu \mathrm{g}$ AGE-BSA yang dicairkan pada larutan phosphate-buffered saline (PBS) yang dikombinasikan dengan CFA (rasio 1:1). Booster imunisasi dilakukan selama 3 kali setiap 14 hari dengan dosis yang sama, CFA diganti dengan IFA untuk booster. Imunisasi dilakukan pada Grup III dan IV.

\section{Induksi DN}

Metode induksi DN pada mencit sesuai metode Tesch \& Allen (2007). STZ (Sigma-Aldrich) dilarutkan dalam $50 \mathrm{~mm}$ buffer asam sitrat. Balb/C dipuasakan semalam dan diinjeksi secara intraperitoneal STZ $55 \mathrm{mg} / \mathrm{kgBB}$ selama 1 x 1 dalam 5 hari. Mencit mengalami DN jika kadar glukosa darah acak $\geq 280 \mathrm{mg} / \mathrm{dL}$ [11]. Injeksi STZ dimulai dua minggu setelah booster imunisasi AGE-BSA terakhir dilakukan. Induksi DN dilakukan pada Grup II dan IV. Setelah 1 minggu post injeksi STZ terakhir, glukosa darah mencit dievaluasi.

\section{Pengukuran Glukosa Darah Acak Mencit}

Level glukosa pada mencit diukur secara enzimatis dari $10 \mu \mathrm{L}$ darah mencit yang diambil pada bagian ekor dan menggunakan Glukometer Nesco. Pengukuran dilakukan selama 6 kali, yaitu pre vaksin, pre booster 1, pre booster 2, pre booster 3, post DN 1, dan post DN 2.

\section{Berat Badan}

Observasi berat badan dilakukan pada saat pre vaksin dan post DN2 menggunakan skala digital Ohauss untuk mendapatkan data yang akurat.

\section{Pengukuran AGE, anti-AGE menggunakan ELISA}

Untuk menghitung kadar AGE serum, sampel didilusi 1:20 dan dikoating pada well 96 semalaman. Kemudian sampel dicuci dengan PBS-Tween 0,2\% selama 3 menit dilanjutkan dengan blok BSA $1 \% \quad 30 \mathrm{~m}$. Antibodi monoclonal anti-AGE (Abcam) didilusi dengan PBS 1:500 dan ditambahkan kedalam well 1 jam. Sampel kembali dicuci dengan PBSTween $0,2 \%$ selama $3 \mathrm{~m}$. Reaksi dilanjutkan dengan mouse anti-Rabbit IgG yang didilusi dengan PBS 1:1000 dilanjutkan dengan avidin biotin dan SaHRP dan stop reaksi dengan $\mathrm{NaOH}$. Sumur plate kemudian ditempatkan pada ELISA reader untuk mendapatkan absorbansi level $(\lambda=450 \mathrm{~nm})$ Untuk menghitung level anti-AGE dalam sirkulasi, metode ELISA digunakan dengan beberapa modifikasi, sampel coating diganti dengan AGE-BSA coating, monoklonal antibodi coating diganti dengan sampel coating (Al Farabi dkk, 2012).

\section{Etik Penelitian}

Etik pada penelitian ini diperoleh dari Komisi

Etik Fakultas Kedokteran Universitas Brawijaya, Malang, Indonesia.

\section{Analisis Data \\ Hasil dianalisa dengan SPSS 17.0 untuk Windows XP menggunakan one way ANOVA dan post Hoc.}

\section{HASIL DAN PEMBAHASAN}

\section{Kadar Glukosa Darah Mencit}

Tujuan pemberian STZ dengan dosis rendah 55 $\mathrm{mg} / \mathrm{kg}$ BB 1x1 selama 5 hari adalah untuk 
menginduksi injuri pada renal mencit. Diabetik nefropati dapat ditegakkan apabila kadar glukosa darah mencapai $\geq 280 \mathrm{mg} / \mathrm{dL}$. Pada penelitian ini, Grup II (kelompok DN tanpa imunisasi) mencapai rata-rata glukosa darah $331 \mathrm{mg} / \mathrm{dL}$ pada minggu ke-12 post STZ terakhir (Tabel 1). Disamping itu, rata-rata glukosa pada Grup IV (imunisasi dan injeksi STZ) berbeda signifikan dengan Grup II, menunjukkan imunisasi mampu menurunkan glukosa darah mencit.

Yang menarik adalah rata-rata glukosa pada Grup III (hanya imunisasi) tidak berbeda signifikan dengan Grup I (mencit normal). Ini mengindikasikan pemberian imunisasi AGEBSA aman terhadap gula darah mencit karena tidak meningkatkan kadar gula darah dan memiliki nilai yang sama dengan Grup I . Perbedaan rata-rata glukosa mencit setiap kelompok secara lebih jelas dapat dilihat pada Gambar dan Tabel 1.

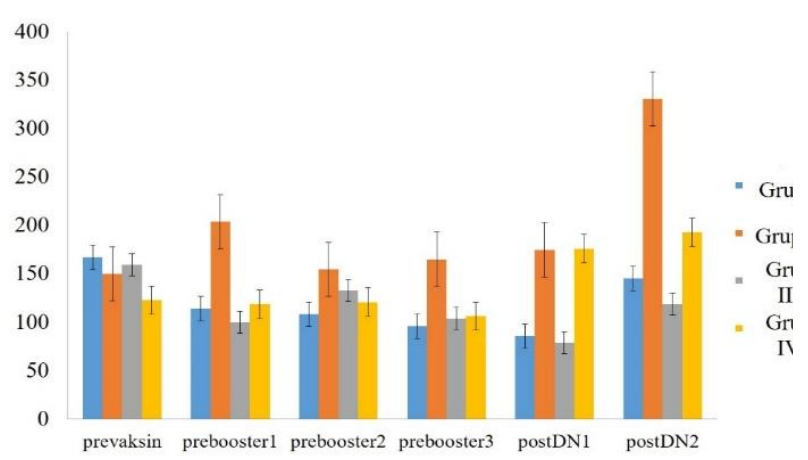

Gambar 1. Kadar glukosa darah acak mencit

Pada Gambar 1, data glukosa darah diambil sebanyak enam kali yaitu sebelum imunisasi (prevaksin), sebelum booster pertama (pre booster 1), sebelum booster kedua (pre booster 2), sebelum booster ketiga (pre booster 3), 1 minggu setelah injeksi STZ terakhir (post DN1), dan 12 minggu setelah injeksi STZ terakhir (post DN2). Terlihat jika pemberian imunisasi AGE-BSA (Grup III) tidak berdampak pada kadar glukosa darah dan bersifat protektif pada saat diinduksi diabetik nefropati (Grup IV).
Tabel 1. Perbandingan kadar glukosa darah acak mencit tiap Grup pada saat sebelum imunisasi dan 12 minggu setelah injeksi terakhir STZ

\begin{tabular}{lll}
\hline Waktu & Kelompok & $\begin{array}{l}\text { Kadar Glukosa } \\
\text { Darah }(\mathrm{mg} / \mathrm{dL})\end{array}$ \\
\hline $\begin{array}{l}\text { Pre } \\
\text { Vaksin }\end{array}$ & Grup I $:$ II $:$ III $:$ IV $=$ & $167: 150: 159: 123$ \\
Post & Grup I $:$ II $:$ III $:$ IV $=$ & $146: 331: 119: 192$ \\
DN 2 & & \\
\hline
\end{tabular}

\section{Kadar AGE dan antibodi anti-AGE serum}

Grup II memiliki kadar serum AGE yang paling tinggi dibandingkan dengan Grup I, III, dan IV ( $\mathrm{p}<0,05)$. Hal ini sebanding dengan penelitian sebelumnya jika pembentukan AGE berasal dari kondisi hiperglikemia [13]. Yang menarik adalah kadar AGE serum pada Grup IV (mencit yang diimunisasi AGE-BSA dan diinjeksi STZ) berbeda signifikan dengan Grup II namun tidak signifikan dengan Grup I dan III, menunjukkan adanya pengaruh protektif imunisasi dalam menghambat pembentukan AGE (Gambar 2).

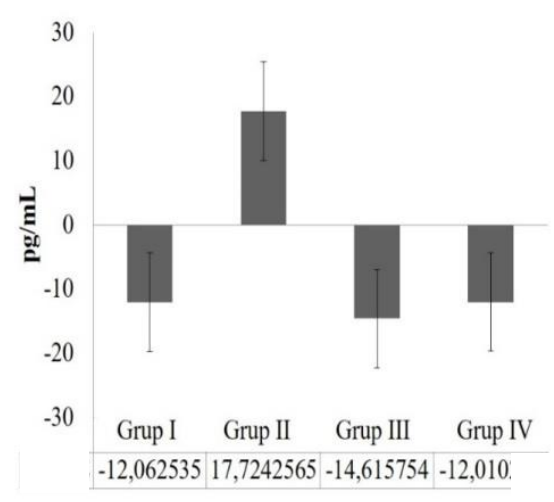

Gambar 2. Kadar AGE serum mencit

Peneliti juga ingin mengetahui kadar antibodi anti AGE dari pemberian imunisasi AGE-BSA kepada mencit yang diinduksi diabetik nefropati, ternyata hasilnya berkebalikan dengan kadar AGE serum. Grup II memiliki kadar AGE paling tinggi dibanding dengan Grup I, III, IV namun memiliki kadar antibodi anti AGE paling rendah dibanding dengan Grup III dan Grup IV ( $p<0,05)$. Ini menunjukkan jika injeksi STZ menginduksi pembentukan AGE namun mencit hanya memproduksi antibodi anti AGE dalam jumlah 
sedikit (Grup II). Dengan dilakukan imunisasi AGE-BSA sebelumnya, ternyata mampu menginduksi produksi antibodi anti AGE sehingga menurunkan glukosa darah dan kadar AGE serum (Grup III dan Grup IV). Grup III dan IV memiliki kadar antibodi anti AGE yang paling tinggi. Kadar antibodi anti AGE serum pada Grup I paling rendah dibandingkan dengan Grup II, III, dan IV karena pada mencit normal memiliki kadar glukosa dan AGE yang rendah / normal sehingga antibodi anti AGE yang terbentuk sangat rendah / dalam batas normal (Gambar 3).

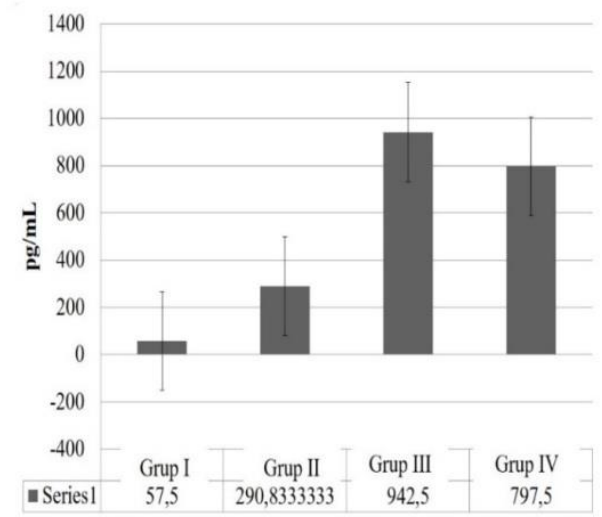

Gambar 3. Kadar antibodi anti-AGE serum mencit

Diabetik nefropati (DN) merupakan salah satu komplikasi serius dari diabetes mellitus dan menjadi penyebab penting dari gagal ginjal stadium akhir (end-stage renal disease / ESRD) $[3,13]$. Salah satu jalur bagaimana kondisi menyebabkan nefropati adalah melalui jalur pembentukan AGE [14]. Pembentukan AGE terbentuk melalui reaksi Maillard dimana gugus karbonil gula tereduksi bereaksi secara nonenzimatik dengan gugus amino pada protein, lipid, dan asam nukleat [15]. Pengikatan kovalen gugus karbonil gula tereduksi dengan gugus amino protein akan membentuk basa Schiff yang bersifat reversibel yang akan mengalami penyusunan ulang spontan menjadi ketoamin yang lebih stabil, disebut Amadori's product. Amadori's product ini yang kemudian berkembang menjadi AGE yang ireversibel [16]. Reaksi tersebut menghasilkan denaturasi, perubahan warna coklat, dan cross-link pada protein target. Kondisi hiperglikemia dalam jangka panjang akan memicu terjadinya proses glikasi lipid dan protein yang mengakibatkan terjadinya peningkatan AGE [17].
Salah satu mekanisme awal AGE mengganggu fisiologis tubuh adalah kemampuannya untuk melakukan cross link, khususnya dengan ECM sebagai media komunikator sel. Hubungan keduanya akan mengacaukan sistem komunikasi sel yang berdampak pada perubahan sinyaling sel dan peningkatan reactive oxygen spesies (ROS). Perubahan ini yang mengawali berbagai penyakit kronik, salah satunya DN yang dimanifestasikan dengan terjadinya glomerulosklerosis dan berlanjut pada gagal ginjal stadium akhir.

AGE disamping memiliki kemampuan dalam cross link, senyawa ini juga mampu berinteraksi antara AGE pada sirkulasi dengan RAGE (receptor for advanced glycation end product) pada sel mesangeal, tubular, dan podosit yang kemudian akan meningkatkan produksi ROS intraseluler dan upregulasi dari factor transkripsi NF- $\mathrm{B}$ yang selanjutnya meningkatkan transkripsi VEGF (vascular endothel growth factor), MCP-1 (monocyte chemoattractant protein-1), ICAM-1 (intercellular adhesion molecule-1), VCAM-1 (vascular cell adhesion molecule-1), CTGF (connective tissue growth factor), sitokin inflamasi IL-1 (interleukin-1), IL-6 (interleukin-6), TNF- $\alpha$ (tumor necrosis factor alpha), dan terutama TGF- $\beta$ (transforming growth factor) sebagai mediator sentral fibrosis [18-24].

Penelitian ini memperkuat teori terkait dampak merugikan hiperglikemia terhadap kadar AGE serum. Pada penelitian ini, terdapat korelasi signifikan antara AGE dengan kadar glukosa ( $p$ value $<0,01)$. Grup II yang diinduksi diabetik nefropati dengan injeksi STZ $55 \mathrm{mg} / \mathrm{kB} 1$ x 1 selama 5 hari memiliki glukosa dan kadar AGE serum paling tinggi dibanding dengan Grup I, III, dan IV, dengan kadar glukosa Grup II sebesar $331 \mathrm{mg} / \mathrm{dL}$ (Grup I = 145; Grup III = 119; Grup IV = 193).

Yang menarik dari hasil penelitian ini adalah kadar AGE serum. Penelitian ini menunjukkan injeksi STZ dengan dosis $55 \mathrm{mg} / \mathrm{kB} 1 \mathrm{x} 1$ selama 5 hari pada Grup II menghasilkan kadar AGE serum paling tinggi dibandingkan dengan Grup I, III, dan khususnya dengan Grup IV (kelompok imunisasi AGE-BSA yang diinjeksi STZ). Grup IV yang telah diimunisasi sebelumnya mampu menghambat pembentukan AGE serum dengan meningkatkan produksi 
antibodi anti-AGE sehingga menyebabkan kadar glukosa darah tidak berada di ambang diabetik nefropati (Tabel 1; Gambar 2 dan 3)

Hasil di atas mendukung penelitian Baydanoff dkk (1996) dan Shibayama dkk (1999) jika AGE yang terbentuk dari berbagai protein terglikasi pada dasarnya memiliki sifat antigenik dan mampu membentuk autoantibodi. Namun permasalahannya pada penelitian tersebut belum diketahui efek dari antibodi anti-AGE bersifat protektif atau justru memperparah DN [25,26]. Stanton et al (1992) menambahkan bahwa AGE memiliki jalur eliminasi, yaitu melalui endositosis makrofag, liver endothelial cell dan kupfer cell yang meliputi berbagai reseptor macrophage scavenging reseptor, Fc $\gamma$ RII-B2 CD36, SR-BI, RAGE dan MARCO reseptor [27]. Penjelasan tersebut dan diselaraskan dengan hasil penelitian ini mengidentifikasi bahwa AGE bersifat antigenik dan imunisasi AGE-BSA bersifat imunoprotektif karena mampu menginduksi antibodi anti-AGE dan membawanya ke dalam jalur eliminasi AGE sehingga menurunkan kadar glukosa dan AGE serum secara signifikan pada mencit yang diinduksi DN.

Pada penelitian juga diamati pengaruh imunisasi AGE-BSA tanpa injeksi STZ, untuk memastikan imunisasi AGE-BSA mampu memproduksi antibodi anti-AGE dan bersifat protektif terhadap kadar glukosa darah dan AGE serum mencit. Hasil penelitian ini sesuai dengan harapan peneliti. Kadar glukosa darah dan AGE serum pada Grup III tidak berbeda signifikan, namun memiliki kadar antibodi anti AGE serum yang tinggi dan berbeda dibandingkan dengan mencit sehat (Grup I). Ini mengindikasikan jika imunisasi AGE-BSA pada mencit sehat akan menstimulasi produksi antibodi anti-AGE serum namun tetap memiliki kadar AGE serum dan glukosa darah yang tidak berbeda dengan Grup I. Pada Grup II, antibodi yang terbentuk tidak mencukupi untuk mendegradasi AGE serum sehingga berdampak pada peningkatan kadar glukosa darah mencit. Dengan demikian, dapat disimpulkan jika pemberian imunisasi AGE-BSA bersifat protektif terhadap kadar glukosa darah dan AGE serum pada mencit sehat maupun mencit diabetik nefropati.

\section{KESIMPULAN}

1. Mencit normal memiliki kadar glukosa darah normal sehingga kadar AGE serum dan antibodi anti AGE serum yang terbentuk sangat rendah

2. Mencit yang diinduksi diabetik nefropati akan memiliki kadar glukosa darah sangat tinggi karena tidak dilakukan imunisasi AGE-BSA sehingga kadar antibodi anti AGE serum rendah yang menyebabkan tingginya kadar AGE serum

3. Imunisasi AGE-BSA bersifat protektif pada glukosa darah dan kadar AGE serum pada mencit sehat dan mencit diabetik nefropati

4. Imunisasi AGE-BSA meningkatkan produksi antibodi anti-AGE pada mencit sehat namun tidak mempengaruhi kadar glukosa darah dan kadar AGE serum (dalam batas normal)

5. Pada mencit yang diimunisasi AGE-BSA sebelumnya, kemudian diinjeksi STZ untuk menginduksi DN ternyata memiliki kadar antibodi anti-AGE serum yang tinggi sehingga mampu menurunkan secara signifikan kadaAGE serumdan kadar glukosa darah

\section{SARAN}

Penelitian ini memiliki beberapa kelemahan. 1) Induksi diabetik nefropati dengan STZ 55 $\mathrm{mg} / \mathrm{kgBB} 1 \mathrm{x} 1$ selama 5 hari kurang efektif karena baru minggu ke-12 post injeksi STZ terakhir, glukosa darah mencit mencapai $\geq 280$ $\mathrm{mg} / \mathrm{dL}$. Kami merekomendasikan menggunakan metode induksi diabetes dan dilanjutkan dengan induksi nepropati, yaitu pertama dengan dosis tunggal STZ 100 $\mathrm{mg} / \mathrm{kgBB}$, dan pada minggu ke-7 dilakukan injeksi kedua STZ dengan dosis $40 \mathrm{mg} / \mathrm{kg}$ 1x1 selama 5 hari [13]. 2) Keyhole Limpet Hemocyanin (KLH) atau lysin perlu ditambahkan sebagai kopling dalam pembuatan vaksinasi AGE-BSA, karena memiliki dampak yang lebih signifikan dalam memberikan proteksi [10, 28]. 3) Untuk penelitian dasar, lebih baik tidak memproduksi vaksinasi secara manual sehingga akan lebih mengetahui secara spesifik efek protektif dari imunisasi AGE. Untuk membuktikan efek protektif imunisasi AGE-BSA, penelitian lebih lanjut diperlukan untuk melengkapi data ini. Pengembangan 
penelitian ini sangat disarankan dalam mewujudkan terapi yang lebih baik dengan keamanan yang tinggi dalam mencegah terjadinya diabetik nefropati.

\section{UCAPAN TERIMA KASIH}

Kami Mengucapkan Terimakasih Kepada Penyedia Dana Hibah Health Professional Education Quality (Hpeq) Yang Merupakan Salah Satu Proyek Dari Direktorat Jenderal Pendidikan Tinggi, Kementerian Pendidikan Dan Kebudayaan Ri. Kepada Mbak Kurnia, Suci, Heni Triwahyuni Kami Ucapkan Terimakasih Banyak Atas Saran, Dukungan, Dan Asistensi Yang Sangat Penting Di Laboratorium Biomedik Fakultas Kedokteran Universitas Brawijaya. Tidak Lupa Kami Berterimakasih Kepada Fakultas Kedokteran Universitas Brawijaya Dan Ibu Agustina Tri Endharti, S.Si, Ph.D Yang Telah Memfasilitasi Proses Pembuatan Manuskrip Penelitian Ini.

\section{DAFTAR PUSTAKA}

[1] Prodjosudjadi W. Incidence, prevalence, treatment and cost of end-stage renal disease in Indonesia. Ethn Dis. 2006;1:S2-S14

[2] Soegondo S, Prodjosudjadi W, Setiawati A. Prevalence and risk factors for microalbuminuria in a cross-sectional study of type-2 diabetic patients in Indonesia: a subset of DEMAND study. Med J Indones. 2009;18:124-130

[3] Stenvinkel, P. Chronic Kidney Disease: A Public Health Priority and Harbinger of Premature Cardiovascular Disease (Review). J Intern Med 2010; 268: 456467.

[4] Dronavalli S, Duka I, and Bakris GL. The Pathogenesis of Diabetic Nephropathy Natur Clinical Practice Endocrinology \& Metabolism Vol. 4(8), 2008.

[5] Bohlender, J. M., Franke S., Stein, G., Wolf , G. Invited Review Advanced Glycation End Products and the Kidney Am J Physiol Renal Physiol 289: F645F659, 2005.

[6] Yamagishi, S. Role of Advanced Glycation End Products (AGEs) and Receptor for AGEs (RAGE) in Vascular
Damage in Diabetes. Experimental Gerontology 46 (2011) 217-224.

[7] Wautier MP, Chappey O, Corda S, et al. 2001. Activation of NADPH oxidase by AGE links oxidant stress to altered gene expression via RAGE. Am J Physiol Endocrinol Metab. 280:E685-94

[8] Goldin, J. A. Beckman, A. M. Schmidt, and M. A. Creager: Circulation 114:597-605, 2006.

[9] Turk, Z., S. Ljubic, N. Turk, and B. Benko. 2001. Detection of Autoantibodies Against Advanced Glycation End Products and AGEImmune Complexes in Serum of Patients with Diabetes Mellitus. Clin.Chim.Acta. 303: 105-115.

[10] Bhatwadekar and V.S. Ghole. 2005. Rapid Method for the Preparation of an AGE-BSA Standard Calibrator Using Thermal Glycation. Journal of Clinical Laboratory Analysis 19:11-15

[11] Greg H Tesch dan Terri J Allen. Rodent models of STZ induced diabetic nephropathy. Nephrology 2007; 12, 261266

[12] Gurley SB, Clare SE, Snow KP, Hu A, Meyer TW, Coffman TM. Impact of genetic background on nephropathy in diabetic mice. Am. J. Physiol. Renal Physiol. 2006; 290: F214-22.

[13] Musthika Wida Mashitah, Nurona Azizah, Nur Samsu, Muhammad Rasjad Indra, Muhammad Bilal, Meti Verdian Yunisa, Amildya Dwi Arisanti. Immunization of AGE-modified albumin inhibits diabetic nephropathy progression in diabetic mice. Diabetes, Metabolic Syndrome and Obesity: Targets and Therapy 2015; 8: 347-355

[14] van Bamme B, Koudstaal J. Measuring glomerular diameters in tissue sections. Virchows Arch A Pathol Anat Histol 1976;369: 283-91.

[15] Liu IM, Tzeng TF, Liou SS, Chang CJ. The amelioration of streptozotocin diabetes-induced renal damage by $\mathrm{Wu}-$ Ling-San (Hoelen Five Herb Formula), a traditional Chinese prescription. J Ethnopharmacol 2009;124:211-8.

[16] Ohshiro, Y., Lee, Y., King., G. L. Mechanism of Diabetic Nephropathy: Role of Protein Kinase-C Activation. ADS Stud Med 2005;5(1A):S10-S19. 
[17] Goldin, J. A. Beckman, A. M. Schmidt, and M. A. Creager: Circulation 114:597-605, 2006.

[18] Basta G, Schmidt AM, De Caterina R. Advanced Glycation End Products and Vascular Inflammation: Implications for Accelerated Atherosclerosis in Diabetes. Cardiovasc

Res. 2004; 63: 582-592.

[19] Goh, Su-Yen and Cooper, ME. The Role of Advanced Glycation End Products in Progression and Complications of Diabetes. J Clin Endocrinol Metab 93: 1143-1152, 2008.

[20] Bohlender, J. M., Franke S., Stein, G., Wolf , G. Invited Review Advanced Glycation End Products and the Kidney Am J Physiol Renal Physiol 289: F645F659, 2005.

[21] Yamagishi, S., Matsui, T. 2010. Advanced Glycation End Products, Oxidative Stress and Diabetic Nephropathy (Review). Oxidative Medicine and Cellular Longevity 3:2, 101-108.

[22] Lee, H. L., Yu, M., Yang, Y., Jiang, Z., Hunjoo, H.A. Reactive Oxygen SpeciesRegulated Signaling Pathways in Diabetic Nephropathy. J Am Soc Nephrol 14: S241-S245, 2003.

[23] Kanwar, Y.S., Wada J., Sun L., Xie P, Wallner EI, Chen S, Chugh S, and
Danesh FR. Diabetic Nephropathy: Mechanisms of Renal Disease Progression Experimental Biology and Medicine 2008, 233:4-11.

[24] Forbes, J., M., Cooper , M. E., Oldfield, M., D., Thomas, M., C. Role of Advanced Glycation End Products in Diabetic Nephropathy. J Am Soc Nephrol 14: S254-S258, 2003.

[25] Baydanoff S, Konova E, Ivanova N: Determination of anti-AGE antibodies in human serum. Glycoconjugate J 13:335339, 1996.

[26] Shibayama,R., Araki,. N., Ejima, Y., Nagai, R., Araki, T., Saya, H., Horiuchi, S. Study of Autoantibodies Against Advanced Glycation Endproducts of the Maillard reaction. Diabetes 48:18421849, 1999.

[27] Stanton, L.W., White R.T., Bryant C.M., Protter A.A., Endemann G. A. Macrophage Fc Receptor for IgG is Also a Receptor for Oxidized Low Density Lipoprotein. J Biol Chem. 1992 Nov 5;267(31):22446-22451.

[28] Makhyan Jibril Al-Farabi, Laili Fitri Ni'amita, Djoko Wahono Soeatmadji, Rasjad Indra. Immunization with $A G E$ $K L H$ Prevent Diabetic Complication in Mice. Indonesian Scholars Journal: 2012. 